DOI: 10.19085/journal.sijmas030903

\title{
Gaps and Bridges in the Diaspora Cultural Life of the Asian-English Muslims in England in Buddha of Suburbia by Hanif Kureishi
}

\author{
Mumtaz Ahmad \\ Assistant Professor English, Government Post Graduate College, Nankana Sahib, Pakistan. \\ PhD Scholar, NUML, Pakistan. \\ (c) Scholedge International Journal of Multidisciplinary \& Allied Studies (ISSN 2394-336X), Vol.03, Issue 09 (2016) pg197-207. \\ Published by: Scholedge R\&D Center [http://www.thescholedge.org/journals/] [Email: editorial@thescholedge.org]
}

\section{Abstract}

This article carries out research in the domain of the issues faced by the first and second generation South-Asian Muslim immigrants in locating identity and their rightful place in postcolonial hybrid culture of England. Location of identity in multi-ethnic metropolitan cultureinvolves the issues of assimilation, segregation, naturalization, racial and cultural discrimination, in-betweeness, hybridity and ambivalence. The Muslim immigrants in an attempt to assimilate themselves into the new culture remain suspended between the two cultures and never completely succeed in embracing the one culture and discarding the other. This state of inbetweenness renders them hybrid characters in the postcolonial conditions. Quite contrary to their sweet dreams and expectations of living a superb life in metropolitan culture,non-white immigrants, Muslims, in the white English societyhave to make multi-dimensional struggle for the discovery and exploration of their unique identity in the face of highly intolerant, xenophobic white societies. The novel, Buddha of Suburbia, has been said to be autobiographical woven from the deeply personal experiences of the author as a member of an ethnic minority, the Muslims, in a multi-ethnic society. The story which initially appears to be fascinating tale of the city turns out to be the story of an Anglo-Asian hybrid. Kureishi has focused on the postcolonial concerns of unstable, fluid identity, gender issues, traumatized and indeterminate sexuality juxtaposed to hypocritical, racially prejudiced binaries-ridden English society.

Key words: post colonialism, hybridity, assimilation, ambivalence, South-Asian Muslims Introduction

In the contemporary era, even after decades of the liberation of colonized countries, the world is sharply divided into developed and less developed countries, into haves and have nots, but it is truly surprising and saddening that the citizens of once subjugated nations are still treated with 
great scorn and contempt by the white societies. Only because they happen to have different cultural, ethnic or religious origin, they are made subject to abject humiliation and unspeakable dehumanization. Instead of personal merits and contents of the character, class, color, cultural ethnicity, religion and nationality have come to be regarded as the criterion of one's superiority and inferiority. The non-white immigrants, particularly, the Muslims from the sub-continent, upon their immigration into the Britain are oppressed and discriminated as backward and insultingly dubbed as 'pakis' believed to be the intruders in the white culture who will contaminate the 'purity' of their culture. But these highly prejudiced advocates of the so -called 'purity' of the white culture, ignore the fact that purity of culture is a myth today and in the wake of decolonization and globalization, the purity and exclusivity of the world cultures have given way to mixedness and hybridity. Living in a compartmentalized culture is not possible today and the constancy or fixedness of a culture is a fable. Hybridity of culture and identity has become a lived and functional reality in any culture of the world, particularly, in the west because of the social and cultural interaction between the nationals of different countries. This hybridization of culture has brought ethno-ideological diversity into British culture which is a phenomenon to be celebrated not shunned.

The Occidental writers seem to misrepresent the Eastern culture and socio-cultural identity of the Easterners by distorting the facts about their human nature, anthropological origin and sociocultural backwardness, showing them to be passive, sentimental, uncivilized brutes born with inferior genes and mentality, fit only to be enslaved and driven like animals. Obviously it demonstrates that such mentality and behaviors of the white people are shaped and influenced by the western construct, the western ideology of binary opposition of Eastern cultural norms and practices as oppressed and backward and Western traditions and modes of living as liberated, developed and superior to it, thus their offensive and even inhuman attitude towards the colored people.

The Western agenda has been to establish the subaltern people to have low origin and degraded cultural background, condemned to be inferior 'others' of the whites. The grossly misleading ideology represents the Orientals as backward and inferior and hence detestable and the western so-called proposition of the white man as superior and civilized. The west has cherished this dangerous misconception that the immigrants from once-colonized countries are threat to the so-called purity of the white culture. The Asian immigrants and their descendants in the raceridden, xenophobic British society grapple with the issues of 'identity crisis' ensuing from the ideological discrepancies between the stronger Britain and the resistant Orientals. The struggle of Kureishi's protagonists in The Buddha of Suburbia to come to terms with their hybrid identity in 
postcolonial British culture manifestly underscores Westerners' resilient resistance and inflexible attitudetowards the Orientals whom they essentialise as inferior and hence treat discriminately.

The novel has been said to be autobiographical woven from the deeply personal experiences of the author as a member of an ethnic minority, the Muslims, in a multi-ethnic society. The story which initially appeared to be the fascinating tale of the city turns out to be the story of an AngloAsian hybrid. Kureishi has focused on the postcolonial concerns of unstable, fluid identity, gender issues, traumatized and indeterminate sexuality juxtaposed to hypocritical, racially prejudiced binaries-ridden English society. Its mega success was ascribed to its quality of being ahead of its time, a futuristic vision and Kureishi, undaunted by the forthcoming 'death of the novel' executed it as his most wonderful, celebrated and influential work. It attracted the attention and warmhearted approbation of not only world-wide readership but also homosexual, bisexual, minoritarian, feminist, postmodernist and post-structuralist audience. Kureishi's uncompromising concern about host of dilemmas facing postcolonial subjects and his frequent discussions of fluid and complex identity coupled with two discordant cultures and values within one protagonist place him within the range of postcolonial studies despite his reservations about being bracketed with postcolonial writers. Overlapping with postcolonial themes, Kureishi concentrates on various kinds of "Othering" relevant to his hybrid characters and lost or dislodged identities. His protagonists' irrefutable and unavoidable biracial and bicultural experience in the country of immigration results in his/her disillusionment with nationalism and jingoism to the effect of liberalism, homosexual relationship and sustained process of self-discovery. On account of his treatment of dual identity and celebration of identity, and postmodern idea of exile, Kureishi crosses corridors with postmodern writers.

\section{Literature Review}

The first critical biography which now, of course, is the most frequently quoted and widely acclaimed as authentic work on Kureishi was Kenneth C. Kaleta'sHanifKureishi, Postcolonial storyteller 1998). Kaleta has incorporated into this monograph critical commentary on Kureishi as a novelist, essayist and screen writer, thus making comprehensive efforts to cover a wide range of Kureishi's oeuvre. The author, himself a distinguished professor of Radio-TV-Film at RowanUniversity in Glassboro, New Jersey is deeply fascinated by and involved in Kureishi's adaptations of his novels and scripts. Kaleta's work on Kureishi is very valuable and profoundly enlightening analysis of Kureishi's works beginning with My Beautiful Launderette and culminating on Love in a Blue Time. 
Bart Moore-Gilbert's HanifKureishi (2001) studies Kureishi's prolific writings into following categories: the plays, the films, the novels and more recent work up to Sleep with Me. The author's crucial review of Kureishi's work is not confined to the traditional approbation of the author under discussion, rather Gilbert has, here and there, taken on Kureishi very critically, passing negative evaluation and very harsh judgment of some of the works of Kureishi, illustrating and supporting his observations with reliable critical material from all available resources: academic journals, newspaper articles, diverse reviews and even Kureishi's own explanations to evaluate Kureishi's literary output.

NahemYousaf'sHanifKureishi'sThe Buddha of suburbia (2002) provides apart from a brief biographical introduction, an interview with HanifKureishi. What follows is the fully elaborated interpretation of the novel and the summary of its reception. Yousaf dwells upon the adaptation of the novel as well and finishes his monograph with fruitful questions for discussion and a list for further reading. Yousaf's work is an admirable contribution towards general comprehension of Kureishi's specific flavor of humor and his idea of post colonialism.

The next vital monograph on Kureishi is a production of Susie Thomas's HanifKureishi (2005). A distinctive feature of this book is unique opportunity for the readers to explore Kureishi's unknown statements and opinions. Thomas has painstakingly explored the critical reception of Kureishi's work and provided the readers with an enormous range of critical perspectives. The monograph consists of nine essays, each covering one of Kureishi's works, and conclusion envisaging Kureishi's future projects. The uniqueness of Bradley Buchanan's HanifKureishi (2007) lies in the provision of an accessible introduction.

\section{Theoretical Framework}

Noticing a nexus between hybridity and postcolonial literature, AniaLoomba (1998) observes in Colonialism / Post colonialism: "postcolonial studies have been preoccupied with issue of hybridity, creolisation, mestizaje, in-betweenness, diasporas and liminaity, with the mobility and cross-overs of ideas and identities generated by colonialism" (p.173). Robert Young (1995) forcefully reminds us that "hybrid technically speaking refers to cross between two different species and that therefore the term hybridization reminds us the botanical notion of interspecies grafting and the vocabulary of the Victorian extreme right which considered different race as different species" (p.10). The Europeans or the whites then with the self-assuring notion of the superiority of the white race consider the non- white races as inferior species not much better than the animals which can be tamed, trained, used, directed and maltreated with impunity because nature had created them in the subservient position. Bhabha drawing 
extensively upon the works of Frantz Fanon describes hybridity and liminality as the corollary of colonial conditions.

Bhabha's use of the term hybridity and liminality strikes original because through these terms he has provided a conceptual vocabulary for colonial and postcolonial studies. His reading methods chiefly inspired by Jacques Derrida and Michel Foucault show that a rigid distinction between the colonizer and colonized is impossible to maintain. Furthermore, through its conceptual vocabulary, Bhaba's work illustrates that the West is never as secure or powerful as it appears or it tries to make itself appear, instead it is troubled by its others, particularly the East. These 'other' or 'doubles' of the west compel it to explain its own identity and justify its rational, civilized self-image. David Huddart (2006) in his book 'Homi K. Bhabha' writes: "[I]n the Location of Culture (1994), Bhabha creates a series of concept that work to undermine the simple polarization of the world into self and other" (p. 4). Bhabha's emphasis on hybridity of culture refers to the mixedness or even impurity of cultures. Hybridity means mixedness within every form of identity whether cultural, racial, social, and linguistic. Cultural hybridity refers to the fact that no culture is pure or discrete phenomenon, rather cultures are always in contact with one another and this contact leads to cultural mixedness. Bhabha is interested less in hybridity and more in hybridization, the latter means on-going process of hybridity. Interestingly Bhabha's study of cultural interaction reveals that these are not the cultures that come together to make hybrid forms; instead cultures themselves are the result of attempts to still the flux of cultural hybridities.

Bhabha explores what happens on the borderlines of the cultures and in between cultures. This is what he calls liminal, meaning that which is on the border or the threshold. The term pinpoints the idea that what is in between settled cultural forms or identities - identities like self and other is central to the creation of new cultural meaning. To give privilege to liminality is to undermine solid, authentic culture in favor of unexpected, hybrid culture. It follows that the proper location of culture is between the overly familiar forms of official culture. The stress on hybrid and liminal is crucial because colonial discourses have set up clear distinctions between pure and discrete cultures. Colonial discourses which are the creation of colonial power followed the policy of dividing the world into self and other in order to rationalize the material inequalities and economic disparity central to the colonial rule. The colonial rule worked on the principle of justifying the subjugating of the inferior races and nations by the powerful white superior nations.

\section{Cross-Racial, Cross-Cultural Gaps and Bridges}


Karim's fascination and intense desire for Charlie in The Buddha of Suburbia is the vivid example of complex representation. Karim's immoderate longing for the white body of Charlie is culturally as well as sexually induced. Charlie's features in accordance with his changeable image are sharp and attractive. Almost throughout the novel, Karim closely tries to imitate his chameleonic changes, naively believing that such emulation and transformation will help him getting himself recognized as a well assimilated person but ironically as well as pathetically, he ends up as a caricature, a butt of ridicule, the one who could be occasionally, sympathized with but not loved or considered equal. In sharp contrast to Charlie's idolized white body- an object of unachievable desire - Karim's brown one is frequently loathed: during performance of The Jungle Book in which he plays the role of Mowgli, he is smeared with disfiguring brown cream presented seminaked in a loin-cloth, of course, much against his wish and to the utter resentment of his childhood friend Jamila; he is subject to shameful sexual degradation frequently, in ways even his own daring sense of sexual adventurousness will not approve of: by the director Pyke, and his lustful wife, Marlene, to whom he is presented as a gift, a toy to play with, an exotic fruit to be tasted and scornfully discarded. Ever a crazy lover of the fashionable and glamorous life of London, though Karim harbors in his heart a strong desire of escaping from dreary suburbs to the stunning life of London, and on actually being in the city of his dreams, dresses himself in the uniforms of London, usually after his Charlie Hero's fashion trends, yet his body bears unmistakable resemblance with Anwar and Changez, both of whom he represents on the stage one crippled, the clumsy husband of his girlfriend, Jamila, and the other decrepit, nostalgic old man starving himself to death to persuade his almost fully westernized daughter to wed him.

Though he is in the artistic and professional world of the theatre, Karim is still an example of the self-help-survivalist Pakistani who with an inordinate ambition to get ahead in the social life of London lets no feeling of guilt or shame come his way. The novel involves one of basic elements of Kureishi's interest - class as basic to assimilation as British born and raised Karim struggles to reconstruct himself into the dominant professions and fashions of the contemporary culture, but this happens at the cost of exploiting the intimate knowledge of his community for pursuing and establishing career in the mainstream world. Burning with the ardent desire of entering the enchanting world of the city, the suburban protagonist of The Buddha of Suburbia,Karim makes his way into the low-brow theatre through the mediation of his father's lover, Eva. His first part, to his horror as well as to the dismay of Jamila and his mother, is the leading role in the Jungle Book where the director, brushing aside his complaint and claims about having the excellent ability to speak in the genuine English accent, reminds him that he is cast "for authenticity and 
not for experiences" (p.147) as Mowgli in a loin- cloth boot polish make up and funny Indian accent.

Always a blatant critic of Karim's lack of sense of self-pride, Jamila, after seeing the performance of the play humiliates him of his shameful appearance in a neo-fascist production and tauntingly says that Karim had absolutely no sense of shame and honor and that he knew only one passion of selfishness. A manifest development in Karim's professional career happens as a he is eyed and offered a role by Mathew Pyke, a distinguished director and an innovator of the successful unconventional theatre.

It is during the working and production of a play with Pyke's group that Karim commits himself with the issue of artistic morality as he experiences with a very clear conscience a sense of guilt towards his community which he can no longer afford to be oblivious of. The characters that the actors are allowed to search and put on the stage are those whose defining feature is their class which according to Pyke is the hot and the only worth discussion subject in England for, the contemporary England is hard to think without class and race issue. Rather than choosing characters for his actors, Pyke, allowing most constructive freedom encourages his actors to explore character from different strata of social array. This method will ensure the actor to select the character they are best acquainted with, helping them to remain closely in touch with reality of the class system in England and present them with high degree of authenticity. However, the only thing that actors will have to make sure is that the characters must belong to their own class that is why when Karim intends to choose his school friend Charlie Hero, the most visible personification of punk cult, Pyke repudiates the suggestion immediately saying that he needed a black person. Paradoxically Karim, after years of living among the white people, would have identified Charlie as "someone from his own background" than he would "someone black," but his compulsion of choosing a black actor continues from Mowglie to the authentic Asian in politically lined play. Disillusioned at not being given freedom to identify himself with the white society the ways and culture of which he has so closely assimilated, Karim is offered only a hobson's choice to base his character on someone from his own family and accordingly he decides to build his character on Anwar, father of his girlfriend, Jamila. Karim had long been acquainted with uncle Anwar, his wife Jeeta and daughter, Jamila and spent a good deal of time with them before deciding to leave suburbs for more exciting life of the city. As before having this new assignment: modeling his character on someone black, someone he intimately knows, he had not observed uncle Anwar so keenly from an actor's point of view, now he frequently visits their shop with the purpose of observing uncle Anwar whose bad decision of forcing his daughter, Jamila to marry a disappointing Indian groom, Changez has left him mentally and 
physically deteriorated, an object of pity and repulsion. For a few weeks that he has for researching and observing his character before the play opens on the stage, Karim follows Anwar's heels, going to the mosque with him, giving Anwar the impression of being his wellwisher, though actually gathering authentic material to display on the stage for the judgmental eye of the whites.

A racist attack on Anwar's shop deals a heavy blow to the already deteriorating state of Anwar, making him "roam the streets" hysterically; yelling at the white boys "beat me, white boy, if you want to!" Anwar's, wife, Jeeta can't help "blush with shame and embarrassment" while recounting this sorry state of affairs to Karim, who ironically, finds in it "just the thing" he was searching for his character sketch. During the rehearsals, he performs his monologue, introducing who Anwar was, his origin and stay in Britain, followed by an imitation of his raving in the streets but instead of getting high flown, congratulatory reception he was anticipating, he invites the consternation rather wrath of the minority member of his cast fellow, Tracey, a black artist usually a reticent girl. Her denunciation speaks volumes in defense of the black as she castigates Karim for his unscrupulous depiction of the black people, thus denigrating the people of his own community.

What Karim had not thought of while choosing an Indian character (weird from the white people's standard of normalcy) and earnestly depicting him for enthusiastic approval of the dramatic persona, was the fact that his representation of the member of his own community will necessarily be deemed as representation of the whole community. With whatever intentions he might have presented the hunger-strike of Anwar, emotionally black mailing his daughter to marry the person of his choice, it will mean to a largely white audience not the psychological portrait of an old Indian man deeply rooted in Indian cultural traditions but as a representation of narrow-minded fanatical black people who despite living for many years among the white people fail to imbibe into their bones the basic cultural patterns of the West, and particularly on growing old, retreat to their parochial thought patterns of primitive Indian culture. And such portrayals depreciating black people will inevitably enrage people of the other communities in similar sociological positions, like Tracey, who strongly believes that that they have to project positive image of their community and culture otherwise their culture will face the danger of extinction.

\section{Karim's Hybrid Identity}

From the very first line of the novel, Karim makes the audience aware of his hybrid identity: "I am an Englishman born and bred, almost. I am often considered to be a funny kind of Englishman, a new breed as it were, having emerged from two old histories ... Englishman I am (though not 
proud of it), from the South London suburbs and going somewhere" (p.3). Karim immediately establishes that he does not neatly fit into rigid racial or national categories, while also acknowledging both his suburban identity and his desire to escape. Readers soon learn that in addition to being the English-born child of an Indian father and an English mother, raised in the suburbs of London, Karim is neither heterosexual nor homosexual, and adheres to no religion. Thus, Karim frustrates easy categorization according to the markers usually used by both governments and individuals, namely, nationality, race, religion and sexual orientation. The only category into which Karim can be neatly placed is that of "suburban teenager." However, it takes Karim much of the novel to realize that the identity that best describes him, places the least restrictions on him, and provides him with the most freedom, is that of suburban.

Karim's hybrid identity is created by a number of factors; however, the most significant factors are the suburban environment and the cultural attitudes of the generation to which Karim belongs.

Ilona considers Karim's generation as one that views identity as not something given or fixed rather it is relational and alterable concept. Not only does Karim adopt and discard various identities, but so do his peers, such as Jamila and the appropriately-named Changez, and, especially, Charlie. Hall's notion of identity in his book Reinventing Britain as process applies particularly well to all of the characters of Karim's generation. Langford argues that Karim's most identifiable characteristic is his ability to accommodate to the difference of others quickly adjusting to the conflicting natures of others. Mark Stein claims that The Buddha of Suburbia disrespects conventional boundaries and refrains from placing its characters exclusively within one type of formation, be it an ethnic group, a cultural group or a class. While Stein's argument generally holds true, and many of the characters do not exclusively inhabit a traditional category, most of the characters could also be placed in a category labelled "suburban," particularly Karim, Charlie, Eva, Haroon, Margaret, Jean, Ted, and Helen.

Kureishi clearly incorporates these ideas into his novel, most notably by creating a protagonist who is a racial, cultural and sexual hybrid. Berthold Schoene claims in Herald of Hybridity; the Emancipation of Difference in HanifKureishi's the Buddha of Suburbia that Kureishi's "greatest achievement" in the novel "is no doubt his creation of Karim, who emerges as a radically deconstructive presence in a world obsessed with clear-cut definitions of cultural or ethnic identity" (p.11)

\section{Conclusion}


The Buddha of Suburbia concludes with Karim accepting an offer to "play the rebellious student son of an Indian shopkeeper" in a soap opera after Karim's return from America (p.259). When considering the offer, Karim notes that the show would have an audience of millions; he would earn huge amounts of money and, more importantly, would be instantly recognized and honored all over the country.

It is apposite that Karim, representative of the new hybrid British identity, should have the opportunity to become a household name through a suburban medium. Head concludes that Karim is "the embodiment of suburban multicultural identity" (p. 87). Kureishi's representation of British nationality in the present day England is strikingly marked with the notion of hybridity as he uncompromisingly believes that in postmodern/postcolonial English society inimitability and purity of culture is impossible phenomenon. His representation of postcolonial South- Asian Muslim immigrant's identity is categorically different from Occidental's essentialist notions of Oriental's identity. Thus, Kureishi not only breaks British literary tradition by producing a complex and cultured suburban environment, he also shuns conventional, deeply rooted notions of British national identity and presents a model for a new hybrid British identity. Karim is, therefore, the typical representative of a new, transformed British identity which is heterogeneous and hybrid.

\section{References}

1. Bhabha, Homi. (1994). The Location of Culture. London: Routledge.

2. Felski, Rita. (2000). "Nothing to Declare: Identity, Shame and the Lower Middle Class". New York: University Press.

3. Hall, Stuart. (1990). A Place Called Home: Identity and the Culture Politics of Difference." Identity: Community, Culture, Difference. Ed. Jonathan Rutherford. London: Lawrence \&Wishart.

4. Huddart, D. (2006). HomiK.Bhaba. London: Routledge

5. Ilona, Anthony. (2003). HanifKureishi's The Buddha of Suburbia: A New Way of Being British.Cambridge: Polity Press.

6. Kaleta, Kenneth. (1998). HanifKureishi: Postcolonial Storyteller. Austin: University of Texas Press.

7. Kureishi, Hanif (1990). The Buddha of Suburbia. London: Faber and Faber.

8. Kureishi, Hanif. (2002). London Kills Me in Kureishi, Hanif, Collected Screenplays. London: Faber and Faber. 
9. Loomba, Ania. (1998). Colonialism Postcolonialism. New York: Routledge.

10. Mcleod, John. (2000). Beginning Postcolonialism. Manchester: ManchesterUniversity Press.

11. Mcleod, John. (2004). Postcolonial London.London: Routledge.

12. Moore-Gilbert, Bark. (2001). Hanif, Kureishi.Manchester: ManchesterUniversity Press.

13. Tew, Philip. (2004). The Contemporary British Novel. London: Continuum Books.

14. Thomas, Susie. (2005). HanifKureishi. New York: Palgrave Macmillan.

15. Yousaf, Nahem. (2002). HanifKureishi's 'The Buddha of Suburbia'. London: Continuum Books. 